\begin{tabular}{|c|c|c|}
\hline & Int.J.Curr.Microbiol.App.Sci (2020) 9(1): 328-333 & \\
\hline & $\begin{array}{l}\text { International Journal of Current Microbiology and Applied Sciences } \\
\text { ISSN: 2319-7706 Volume } 9 \text { Number } \mathbf{1}(\mathbf{2 0 2 0 )} \\
\text { Journal homepage: http://www.ijcmas.com }\end{array}$ & $\Rightarrow 0$ \\
\hline $\begin{array}{l}\text { EXCELLENT } \\
\text { PUBLISHERS }\end{array}$ & & whww ijemas \\
\hline
\end{tabular}

Original Research Article

https://doi.org/10.20546/ijcmas.2020.901.037

\title{
Survey for the Incidence of Stem Rot of Groundnut in North Bengal Districts of West Bengal, India
}

\author{
S. Baskey ${ }^{1^{*}}$, S. Khalko ${ }^{2}$, S. Hembram ${ }^{2}$, B. R. Sharma ${ }^{3}$ and S. Ali $^{3}$ \\ ${ }^{1}$ AICRP on MAP\&B, UttarBanga Krishi Viswavidyalaya, Regional Research Station (Hill \\ Station) Kalimpong -734301, West Bengal, India \\ ${ }^{2}$ Department of Plant Pathology, UttarBanga Krishi Viswavidyalaya, \\ Pundibari -736165, West Bengal, India \\ ${ }^{3}$ Department of Plant Pathology, Regional Research Station (Hill Station) \\ Kalimpong -734301, West Bengal, India \\ *Corresponding author
}

Keywords

Groundnut, Disease incidence, Survey,

Stem Rot, North

Bengal districts,

West Bengal

Article Info

Accepted:

15 December 2019

Available Online:

20 January 2020
A B S T R A C T

Groundnut (Arachis hypogaea L.) is an important edible leguminous oilseed crop. Diseases of groundnut act as the limiting factor to its economic production. Recently, the stem rot caused by Sclerotium rolfsii is becoming severe disease of groundnut in India. Crop Losses up to 59 per cent due to stem rot disease have been reported by many researchers. Hence, to get a preliminary an idea regarding the incidence level and pattern of prevalence of the disease in the agro-ecological condition of northern part of West Bengal, fixed plot and roving survey were conducted at different locations during the crop growing season of 2016-17 and 2017-18. The North Bengal part of West Bengal denotes Jalpaiguri Division (Alipurduar, Cooch Behar, Darjeeling, Jalpaiguri and Kalimpong) and Malda division (Uttar Dinajpur, Dakshin Dinajpur and Malda) together. It also includes parts of Darjeeling Hills. Traditionally, the Ganga River divides West Bengal into South Bengal and North Bengal, divided again into Terai and Dooars regions. The pooled analysis of two years data of survey revealed that disease incidence was ranged from 8.16 to $25.89 \%$ and the Alipuduar district had maximum level of disease incidence ranging from 8.16 to $25.89 \%$ followed by Jalpaiguri district 13.41 to $22.49 \%$, Coochbehar district 11.46 to $18.81 \%$, Darjeeling district 8.25 to $16.26 \%$, Uttar Dinajpur district 9.36 to $14.71 \%$, Dakhin Dinajpur district 8.91 to $13.67 \%$,.However, Malda district was noticed with less incidence levels ranging from 8.16 to $12.37 \%$. This study provided an elementary idea about the percent disease incidence (PDI) as well as paved the path for developing location specific good agricultural practices (GAP). 


\section{Introduction}

Groundnut (Arachis hypogaea L.) is an important edible leguminous oilseed crop. Diseases of groundnut act as the limiting factor to its economic production. Due to its extensive cultivation, different biotic and abiotic factors have emerged as a major constraint in the successful cultivation of groundnut. Among the biotic factors, different diseases i.e., Botrytis blight (Botrytis cinerea), Charcoal rot (Macrophomina phaseolina), Cylindrocladium black rot (Cylindrocladium crotalariae), Early leaf spot (Cercospora arachidicola), Late leaf spot (Cercospora personatum), Phyllostica leaf spot (Phyllostica arachidis hypogaea),Rust (Puccinia arachidis),Sclerotinia blight (Sclerotinia minor),Verticillium wilt (Verticillium spp.),Web blotch (Phoma leaf spot) (Phoma arachidicola),Stunt Peanut stunt virus (PSV),Tomato spotted wilt virus \& Peanut bud necrosis Tomato spotted wilt virus (TSWV),Peanut bud necrosis virus (PBNV) (Meah, 2003). But recently, the stem rot caused by Sclerotium rolfsii is becoming severe disease of groundnut in India. It caused $80 \%$ per cent of crop loss in groundnut (Mehan et. al., 1990). Ray et al., (1994) reported stem rot caused by Sclerotium rolfsii (Corticium rolfsii) is one of the major threats in India, with an incidence of 59\%. Singh and Mathur (1953) reported stem rot caused by Sclerotium rolfsii (Corticium rolfsii) is one of the major threats in Kanpur, Uttar Pradesh, India, with an incidence of $27 \%$. The disease is widely distributed in tropical and sub-tropical regions where high temperature prevails. Sclerotium rolfsii, the causal agent of stem rot of many crops (Aycock, 1966) having a wider host range attracted the attention of plant pathologist and professional researcher throughout the world. The pathogen is known to cause diseases of cereals, oil crops, pulses, vegetables, ornamentals, and in the nurseries of seedlings of fruits and forest trees (Bertus,
1929). The pathogen is a soil inhabitant, very aggressive nature, attacks at soil-line, which ultimately leads to wilting and ultimate to its death. The infection leads to the drying of lower leaves and eventually the whole plant dries giving a typical symptom of wilting. The stem rot of groundnut may occur at any growth stage of the plant (Begum et al., 1985). The disease has been reported by many researchers in different agro climatic zone of West Bengal. But accurate information of disease incidence and severity of the disease particularly in the northern part of West Bengal is scanty. Inadequate knowledge of, the intensity of the disease, epidemiology and their distribution pattern etc. in respect to groundnut cultivation, which leads to the use of pesticide indiscriminately and cause environmental degradation. The North Bengal part of West Bengal denotes Jalpaiguri Division (Alipurduar, Cooch Behar, Darjeeling, Jalpaiguri and Kalimpong) and Malda division (Uttar Dinajpur, Dakshin Dinajpur and Malda) together. It also includes parts of Darjeeling Hills. Traditionally, the Ganga River divides West Bengal into South Bengal and North Bengal, divided again into Terai and Dooars regions. The Hill areas of Darjeeling District are located within the lesser and Sub - Himalayan belts of the Eastern Himalayas. The area is bounded by the Sikkim Himalaya in the north, the Bhutan Himalaya in the east and Nepal Himalaya in the west. The elevation varies from $100 \mathrm{~m}$. above sea level to the mighty Kanchanjungha. There are different climatic zones with distinctive attributes along with endangered Medicinal and Aromatic Plants are available in this region. The average rainfall of the study area is about 2500-3,500 mm. Monsoon generally starts from the middle of May, temperature ranges $18^{\circ} \mathrm{C}-30^{\circ} \mathrm{C}$ and it continues till the end of September. Winters are cold with foggy mornings and nights; temperature ranges $10^{\circ} \mathrm{C}-21^{\circ} \mathrm{C}$. Summer is mild and constitutes a very short period of the 
year; temperature ranges $15^{\circ} \mathrm{C}-25^{\circ} \mathrm{C}$. The altitude of study area ranges from 90 to 1,950 $\mathrm{m}$. No baseline data on stem rot disease of groundnut of North Bengal is available till now. Therefore, the present study was carried to find out the incidence, severity and distribution pattern of stem rot disease of groundnut in different agro-ecological condition of northern part of West Bengal. India.

\section{Materials and Methods}

Fixed plot surveys were carried out during the crop growing season of 2016-17 and 2017-18 to estimate the disease incidence of stem rot disease of groundnut under the different agroecological condition of northern part of West Bengal. North Bengal covers the area of the district, like Malda, Uttar Dinajpur, Dakkhin Dinajpur, Darjeeling, Alipurduar, Cooch Behar and Jalpaiguri, where groundnut crop was cultivated by the farmers. At a Random, uniform fields were selected in each location, and observation on the disease incidence of stem rot was recorded by using disease rating formula. The recorded data of disease incidences of stem rot have been presented in the table 1 .

Percent Disease Incidence (PDI)

Number of plants showing wilting symptom

$=\ldots \ldots \ldots \ldots \ldots \ldots \ldots . . . . . \ldots 100$

Total number of plants

\section{Results and Discussion}

The pooled analysis of two years data of survey revealed that disease incidence was ranged from 8.16 to $25.89 \%$ in north Bengal districts and the Alipuduar district had maximum level of disease incidence ranging from 8.16 to $25.89 \%$ followed by Jalpaiguri district 13.41 to $22.49 \%$, Coochbehar district 11.46 to $18.81 \%$, Darjeeling district 8.25 to $16.26 \%$, Uttar Dinajpur district 9.36 to $14.71 \%$, Dakhin Dinajpur district 8.91 to $13.67 \%,$. However, Malda district was noticed with less incidence levels ranging from 8.16 to $12.37 \%$. It was also observed that While comparison of the district-wise incidence level of stem rot disease in six districts, the pooled analysis (Table 1 and Fig. 1) indicated that the Alipurduar district had maximum level of disease incidence $19.25 \%$ followed by Jalpaiguri district $18.45 \%$, Coochbehar district 16.51\%, Darjeeling district $13.69 \%$, Uttar Dinajpur district $12.55 \%$, Dakkhin Dinajpur district $11.75 \%$, Malda district was noticed with less incidence levels $10.21 \%$ during seasons under surveyed, However, Among the locations surveyed, percent disease incidence was highest at Paschim Degaon village of Falakata block under Alipurduar district during both the years of survey $(25.89 \%)$ while, it was lowest with $8.16 \%$ at Detola village of Gazole block, under Malda district.

This variation in disease incidence may be due to the edaphic factors. These results are in conformity with the findings of Mehan and McDonald (1990) where it was observed that the Stem rot is one of the major constraints in groundnut production as it severely affects the yield and quality of the produce. Kumar et al., 2013 also recorded that In India, it occurs in all groundnut growing states and most severe in Andhra Pradesh, Maharashtra, Gujarat, Madhya Pradesh, Karnataka, Orissa and Tamil Nadu and Yield losses range from 10 to $25 \%$ annually. The disease incidence will be more severe reach upto $80 \%$ during stem rot epidemics coincides with wet climatic conditions prevailed at pod filling (Akgul et al., 2011). 
Table.1 Stem rot incidence in northern districts of West Bengal during 2016-17 \& 2017-2018 (Pooled analysis)

\begin{tabular}{|c|c|c|c|c|c|c|}
\hline $\begin{array}{l}\text { Sl. } \\
\text { No }\end{array}$ & $\begin{array}{l}\text { Name of } \\
\text { District }\end{array}$ & $\begin{array}{l}\text { Name of } \\
\text { Block }\end{array}$ & Name of Village & $\begin{array}{c}\text { No of Field } \\
\text { Surveyed }\end{array}$ & $\begin{array}{c}\text { Village wise } \\
\text { disease } \\
\text { Incidence }\end{array}$ & $\begin{array}{c}\text { District wise } \\
\text { disease } \\
\text { incidence }\end{array}$ \\
\hline \multirow[t]{14}{*}{1} & \multirow[t]{14}{*}{ Alipurduar } & Alipurduar II & $\begin{array}{c}\text { TirlaTola } \\
\text { (Shamuktola) }\end{array}$ & 4 & 23.71 & \multirow[t]{14}{*}{19.25} \\
\hline & & Alipurduar II & Boropukhuria & 3 & 19.32 & \\
\hline & & Alipurduar II & Baniagaon & 3 & 21.35 & \\
\hline & & Alipurduar-I & Shimlabari & 5 & 24.45 & \\
\hline & & Falakata & Pashim Degaon & 3 & 25.89 & \\
\hline & & & Satpukhuria & 3 & 17.98 & \\
\hline & & Kalchini & $\begin{array}{l}\text { Biswanathpara } \\
\text { (Hemiltanganj) }\end{array}$ & 3 & 8.16 & \\
\hline & & Kalchini & Satali Bosti & 3 & 19.35 & \\
\hline & & Kalchini & Machpara & 3 & 17.39 & \\
\hline & & Kumargaram & Paglarhat & 3 & 17.31 & \\
\hline & & Kumargaram & Marakhata & 3 & 16.25 & \\
\hline & & Kumargaram & Khowardanga & 3 & 13.24 & \\
\hline & & Madarihat & $\begin{array}{l}\text { Hantapara Bagan } \\
\text { bosti }\end{array}$ & 4 & 15.24 & \\
\hline & & Madarihat & $\begin{array}{c}\text { Shishu-Bosti } \\
\text { (Shishu-jhumra) }\end{array}$ & 4 & 18.98 & \\
\hline \multirow[t]{6}{*}{2} & \multirow[t]{6}{*}{ Jalpaiguri } & MalBazar & Gazole Doba & 4 & 22.49 & \multirow[t]{6}{*}{18.45} \\
\hline & & MalBazar & Borodighi & 4 & 21.89 & \\
\hline & & MalBazar & Mathachulka & 3 & 13.41 & \\
\hline & & Nagrakata & Sukani Bosti & 3 & 18.92 & \\
\hline & & Nagrakata & khayerBari & 3 & 17.65 & \\
\hline & & Nagrakata & Shalgapara & 3 & 15.91 & \\
\hline \multirow[t]{3}{*}{3} & \multirow[t]{3}{*}{ Coochbehar } & Pundibari & UBKV Farm & 3 & 18.81 & \multirow[t]{3}{*}{16.51} \\
\hline & & Pundibari & $\begin{array}{l}\text { KhagriBari } \\
\text { (Patlakhawa) }\end{array}$ & 3 & 17.56 & \\
\hline & & Dinhata & Santalpara & 3 & 11.46 & \\
\hline \multirow[t]{3}{*}{4} & \multirow[t]{3}{*}{ Darjeeling } & Kharibari & GodhiraJote & 4 & 16.26 & \multirow[t]{3}{*}{13.69} \\
\hline & & Kharibari & Kopalashi & 4 & 15.69 & \\
\hline & & Kharibari & Urlajote & 4 & 8.25 & \\
\hline \multirow[t]{3}{*}{5} & \multirow{3}{*}{$\begin{array}{c}\text { Uttar } \\
\text { Dinajpur }\end{array}$} & Itahar & Noliyabad & 4 & 9.36 & \multirow[t]{3}{*}{12.55} \\
\hline & & Itahar & Modonia & 3 & 13.27 & \\
\hline & & Itahar & Boidra & 3 & 14.71 & \\
\hline \multirow[t]{3}{*}{6} & \multirow{3}{*}{$\begin{array}{l}\text { Dakkhin } \\
\text { Dinajpur }\end{array}$} & Buniadpur & Nilgombhir & 4 & 13.67 & \multirow[t]{3}{*}{11.75} \\
\hline & & Buniadpur & Bodolpur & 3 & 12.89 & \\
\hline & & Buniadpur & Sisha & 3 & 8.91 & \\
\hline \multirow[t]{3}{*}{7} & \multirow[t]{3}{*}{ Malda } & Gazole & Bhaluk Danga & 3 & 12.37 & \multirow[t]{3}{*}{10.21} \\
\hline & & Gazole & Jamalpur & 4 & 11.85 & \\
\hline & & Gazole & Deotola & 3 & 8.16 & \\
\hline
\end{tabular}


Fig.1 Stem rot disease incidence in northern districts of West Bengal

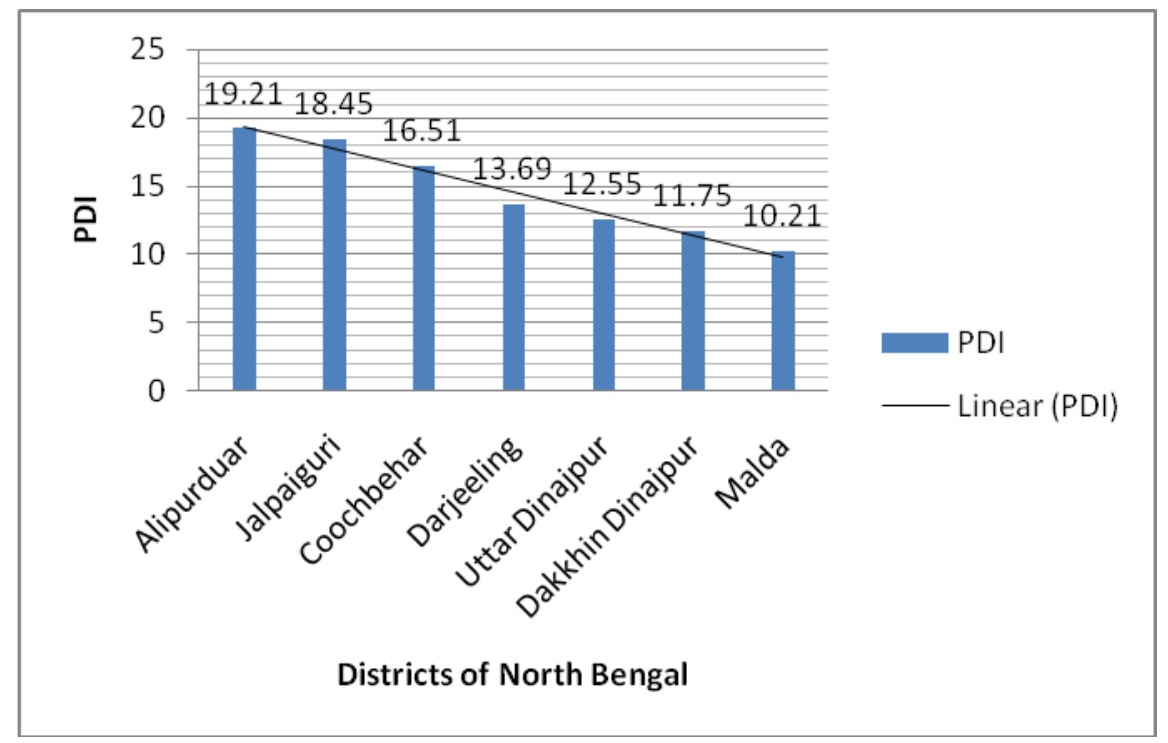

The results obtained in this experimental study revealed that the stem rot of groundnut caused by Sclerotium rolfsii was prevalent in all the north Bengal districts of West Bengal. The district Alipurduar showed maximum disease incidence of stem rot whereas minimum disease incidence was recorded in Malda district. The conducive weather parameters, soil type, and continuous cultivation of susceptible cultivars over the years, were responsible for higher percent disease incidence (PDI)in these locations. The finding emphasize on area specific good agricultural practices (GAP) needs to be develop to cope up the loss due to stem rot disease of ground nut.

\section{References}

Akgul, D.S., Ozgonen, H and Erkilic, A. 2011. The effects of seed treatments with fungicides on stem rot caused by Sclerotium rolfsii Sacc in peanut. Pakistan Journal of Botany. 43 (6): 2991-2996.

Aycock, R., 1966. Stem rot and other diseases caused by S. rolfsii. Tech. Bull. No.174. Agric. Expt. Station, North
Carolina State University, Raleigh. 202 p.

Begum, S. N., Chowdhury, B. C., and Ahamed, H. U., 1985. Screening of brinjal varieties for resistance to $\mathrm{S}$. rolfsii. Abst. 1st National Conf. Plant Pathology, held at Bangladesh Agricultural Research Institute, Joydebpur, Gazipur. 12 p.

Bertus, L. S., 1929. Sclerotium rolfsii in Cylon. Ann. Royal Botanical Garden Peradeniya XI (2): 173-187.

Ganesan, S., Kuppusamy, R and Sekar, R. 2007. Integrated management of stem rot disease (Sclerotium rolfsii) of groundnut (Arachis hypogaea L.) using Rhizobium and Trichoderma harzianum. Turkish Journal of Agriculture and Forestry. 31: 103-108.

Kumar, N., Dagla, M.C., Ajay, B.C., Jadon, K.S and Thirumalaisamy, P.P. 2013. Stem Rot: A Threat to Groundnut Production. Popular Kheti. 1 (3): 2630.

Meah, M. B., 2003. Integrated management of Eggplant cultivation-1. IPM laboratory, Department of Plant Pathology, Bangladesh Agricultural 
University, Mymensingh. Bangladesh. 3-15 pp.

Mehan, V.K and McDonald, D. 1990. Some Important diseases of groundnut sources of resistance and their utilization in crop improvement. Paper presented at the In Country Training Course on Legumes Production. Pp. 917.

Punja, Z.K. 1985. The biology, ecology and control of Sclerotium rolfsii. Annual
Reviews of Phytopathology. 23: 97127.

Ray,S.K.1994. Biological control of soil borne diseases and crop health by inhibition microorganisms. Ph.D, thesis submitted to Bidhan Chandra Krishi Viswavidyalaya, West Bengal, India. pp. 187

Singh and Mathur,S.C. 1953. Sclerotial root rot disease of groundnut in Uttarpradesh. Curr. Sci, 22:214-215

\section{How to cite this article:}

Baskey, S., S. Khalko, S. Hembram, B. R. Sharma and Ali, S. 2020. Survey for the Incidence of Stem Rot of Groundnut in North Bengal Districts of West Bengal, India. Int.J.Curr.Microbiol.App.Sci. 9(01): 328-333. doi: https://doi.org/10.20546/ijcmas.2020.901.037 